Available online at GSC Online Press Directory

GSC Biological and Pharmaceutical Sciences

e-ISSN: 2581-3250, CODEN (USA): GBPSC2

Journal homepage: https://www.gsconlinepress.com/journals/gscbps

(RESEARCH ARTICLE)

\title{
Synergistic larvicidal action of Citrus limon (L.) Osbeck (Rutaceae) and Bacillus thuringiensis Berliner 1915 (Bacillaceae) against the dengue vector Aedes aegypti Linnaeus 1762 (Diptera: Culicidae)
}

\author{
Marin Grace ${ }^{1}$, Arivoli Subramanian ${ }^{2}$ and Tennyson Samuel 3,* \\ 1 Department of Zoology, Scott Christian College, Nagercoil 629 003, Tamil Nadu, India. \\ 2 Department of Zoology, Thiruvalluvar University, Vellore 632 115, Tamil Nadu, India. \\ ${ }^{3}$ Department of Zoology, Madras Christian College, Chennai 600 059, Tamil Nadu, India.
}

Publication history: Received on 23 December 2019; revised on 08 January 2020; accepted on 09 January 2020

Article DOI: https://doi.org/10.30574/gscbps.2020.10.1.0249

\begin{abstract}
Botanical and microbial insecticides are promising alternatives to synthetic pesticides for mosquito control because of lower toxicity to non-target organisms and their innate biodegradation ability. The present study was aimed to determine the synergistic larvicidal action of Citrus limon and Bacillus thuringiensis on the dengue vector Aedes aegypti. The crude methanolic leaf extract of Citrus limon and Bacillus thuringiensis were tested separately on the third instar larvae of Aedes aegypti at concentrations of 100, 200, 300, 400 and $500 \mathrm{mg} / \mathrm{L}$ and at 0.5, 1.0, 1.5, 2.0 and 2.5 mg/L respectively. Larval mortality was observed after 24 and 48 hours and the corresponding LC 50 values were 285.1 and $219.5 \mathrm{mg} / \mathrm{L}$ for Citrus limon and 1.9 and $1.4 \mathrm{mg} / \mathrm{L}$ for Bacillus thuringiensis respectively. The synergistic larvicidal action showed high mortality and its LC 50 values were 158.5 and $109.9 \mathrm{mg} / \mathrm{L}$ after 24 and 48 hours of exposure respectively. This synergistic interaction was due to the phytocompounds of Citrus limon and toxins from Bacillus thuringiensis which showed toxicity on the larvae of the dengue vector, Aedes aegypti. Hence, the exploitation of plant chemicals and microbial pesticides can be suggested for use in mosquito vector control program for the control of mosquitotransmitted diseases.
\end{abstract}

Keywords: Citrus limon; Bacillus thuringiensis; Aedes aegypti; larvicidal; Synergistic action

\section{Introduction}

Mosquitoes present an immense threat to millions of people worldwide, since they act as vectors for malaria, Japanese Encephalitis, filarial and yellow fever, dengue, chikungunya and Zika virus fever [1, 2]. The misuse and overuse of synthetic pesticides have led to the vast destruction of beneficial organisms along with detrimental effects on the environment. The war against mosquitoes by method for concoction pesticides has fizzled because of the resistance created by mosquitoes [3]. Botanicals and microbial pesticides are promising alternatives for mosquito control because of lower toxicity to non-target organisms and their innate biodegradation ability. A number of plants and microbes have been reported as selectable subjects with little or no harmful effect on non-target organisms and the environment. Phytochemicals derived from plant sources act as larvicides and researches have proved the effectiveness of plant derived secondary compounds, viz., alkaloids [4, 5], flavonoids [6, 7], saponins [8, 9], steroids [10], and tannins [11] as mosquito larvicides. Besides these, microbial insecticides is also an important component of the integrated vector control strategy, wherein Bacillus thuringiensis a bacterium which produces bacteriocin compounds of insecticidal properties is a well-known bacterial agent which have been used successfully for mosquito control [12].

\footnotetext{
${ }^{*}$ Corresponding author

E-mail address: samtennyson@gmail.com
} 
Citrus species well known for its economic importance has been identified for its larvicidal activities. The potential use of extracts from Citrus species as a mosquito larvicide has been studied, viz., Citrus aurantium (sour orange), Citrus grandis (pomelo), Citrus aurantifolia (key lime) [13], Citrus limon (lemon), Citrus sinensis (red blood orange), Citrus paradisi (grapefruit), Citrus reticulata (mandarin orange) [14], Citrus mitis (calamondin), Citrus jambhiri (rough lemon) [15] and Citrus limetta (sweet lime) [16] against Aedes aegypti, and Citrus limon, Citrus paradisi and Citrus sinensis against Culex pipiens [17]. Microbial insecticides on the other hand, due to their selective toxicity and ready decomposability in the ecosystem, are being considered as alternatives to chemical insecticides as through their metabolites they act as potential mosquito larvicides. The genus Bacillus is extensively studied for mosquitocidal properties. Bacillus thuringiensis, Bacillus sphaericus have been used for mosquito control [18-20], Bacillus alvei, Bacillus brevis [21], Bacillus circulans [22] and Bacillus subtilis [23] are reported to produce mosquitocidal toxins. Thus, this study was aimed to determine the synergistic larvicidal action of Citrus limon and Bacillus thuringiensis on the dengue vector Aedes aegypti.

\section{Material and methods}

\subsection{Plant collection and preparation of phytoextracts}

Mature and healthy leaves of Citrus limon were collected from Nagercoil, Kanyakumari district, Tamil Nadu, India. Taxonomical identity of the plant was confirmed at Department of Botany and Research Centre, Nagercoil, Kanyakumari district, Tamil Nadu, India. The leaves were then brought to the laboratory, washed in dechlorinated water, shade dried and powdered with the aid of an electric blender separately. The powdered plant parts $(250 \mathrm{~g})$ were extracted with methanol $(750 \mathrm{~mL})$ in a Soxhlet apparatus [24]. The crude solvent leaf extract thus obtained were then stored in air tight sterilized amber coloured bottles at $4^{\circ} \mathrm{C}$ for bioassay.

\subsection{Phytochemical screening}

The active phytochemical substances in Citrus limon leaf extracts were qualitatively determined using the various methods described by Harborne [25] for alkaloids and phenolics, Van Burden and Robinson [26] for tannins, Obadoni and Ochuko [27] for saponins, Boham and Kocipai [28] for flavonoids, and Okwu and Okwu [29] for vitamins.

\subsection{Microbial collection and preparation}

Bacillus thuringiensis was obtained from Inbiotics laboratory, Nagercoil, Tamil Nadu, India. The required quantity of this microbe was thoroughly mixed with distilled water for bioassay.

\subsection{Test mosquitoes}

The eggs of Aedes aegypti were obtained from Entomology Research Institute, Loyola College, Chennai, Tamil Nadu, India which were free of exposure to insecticides. Cyclic generations of this vector mosquito was maintained separately in mosquito cages (2'x2'x2') in an insectary with a mean room temperature of $27 \pm 2^{\circ} \mathrm{C}$ and a relative humidity of 70 -80 $\%$. The adult mosquitoes were fed on ten per cent glucose solution in water. The eggs laid in ovitraps placed inside the mosquito cages were then transferred to enamel larval trays maintained in the larval rearing chamber. The larvae were fed with larval food (dog biscuits and yeast in the ratio 3:1). The larvae on becoming pupae were collected, transferred to plastic bowls and kept inside another mosquito cage for adult emergence.

\subsection{Larvicidal bioassay}

Larvicidal bioassay was carried out as per the guidelines of World Health Organization with minor modifications [30]. Larvicidal activity at test concentrations of 100, 200,300, 400 and $500 \mathrm{mg} / \mathrm{L}$ for the plant and at 0.5, 1.0, 1.5, 2.0 and $2.5 \mathrm{mg} / \mathrm{L}$ for the microbial extract and in addition, their synergistic activity was also assessed. The required test concentrations and quantity of test solution was prepared by serially diluting one per cent stock solution of the crude extract. Third instar of larvae compared to first and second instar have a larger body size and more adaptive to the environment while fourth instar in approximately 48 hours will turn into a pupa which formed the basis for selection of the third instar larva as the research sample. Twenty five early third instar larvae from laboratory colonized Aedes aegypti of $\mathrm{F}_{1}$ generation were introduced into glass beakers $(250 \mathrm{~mL})$ containing $200 \mathrm{~mL}$ of distilled water and test concentration. Untreated control (distilled water) and treated control (Tween 80 added + distilled water) were maintained separately and run simultaneously. Mortality was observed 24 and 48 hours after treatment. Moribund larvae were scored dead when they showed no signs of movement when probed by a needle at their respiratory siphon. A total of five replicates per trial and a total of three trials for each concentration were carried out. 


\subsection{Statistical analysis}

The per cent larval mortality was calculated using the formula (1) and corrections for control mortality (5-20\%) when necessary was done using formula (2) of Abbott's [31]. Statistical analysis of all mortality data of larvicidal activity were subjected to probit analysis. ANOVA and regression analysis tests were used to determine if the mortality in treated bioassays significantly differed from that of the controls and at which doses in particular and the differences were considered as significant at $P \leq 0.05$ level. All statistics were conducted in IBM SPSS Statistics v 22 with significance set at $95 \%$ confidence [32].

$$
\text { Per cent larval mortality }(1)=\frac{\text { Number of dead larvae }}{\text { Number of larvae introduced }} \times 100
$$

$$
\text { Corrected percentage of control mortality }(2)=\frac{1-n \text { in } T \text { after treatment }}{n \text { in } C \text { after treatment }} \times 100
$$

Where, $n$ is the number of larvae, T: treated and C: control.

\section{Results}

The preliminary qualitative phytochemical analysis of Citrus limon methanolic leaf extract tested positive for flavonoids, flavones, limonene, folic acid, tannins, vitamins A, B1 and C. No larval mortality was observed in treated and untreated control. The mean and percentage mortality of Aedes aegypti larva treated with the various concentration of Citrus limon extract after 24 and 48 hours are presented in Figure 1 and its $\mathrm{LC}_{50}$ values after 24 and 48 hours are 285.1 and 219.5 mg/L respectively (Table 1). The mean and percentage mortality of Aedes aegypti larva treated with the various concentration of Bacillus thuringiensis extract after 24 and 48 hours are presented in Figure 2 and its $\mathrm{LC}_{50}$ values are 1.9 and $1.4 \mathrm{mg} / \mathrm{L}$ after 24 and 48 hours respectively (Table 1). The synergistic effect of the plant and microbe exerted a marked inhibitory effect on Aedes aegypti larvae which was visibly noted by its movement. The mean and percentage mortality of Aedes aegypti larva caused due to the synergistic activity after 24 and 48 hours are presented in Figure 3 and its corresponding $\mathrm{LC}_{50}$ values are 158.5 and $109.9 \mathrm{mg} / \mathrm{L}$ respectively (Table 1). Regression analysis relationship between the plant extract, microbial and their synergistic activity was highly significant which indicated marked effect on the larva of Aedes aegypti. Further, ANOVA revealed the relationship between larval mortality in reference with concentration of Citrus limon and Bacillus thuringiensis as well as their synergistic extract which indicated that the increasing concentrations had a significant effect on Aedes aegypti (Table 1).

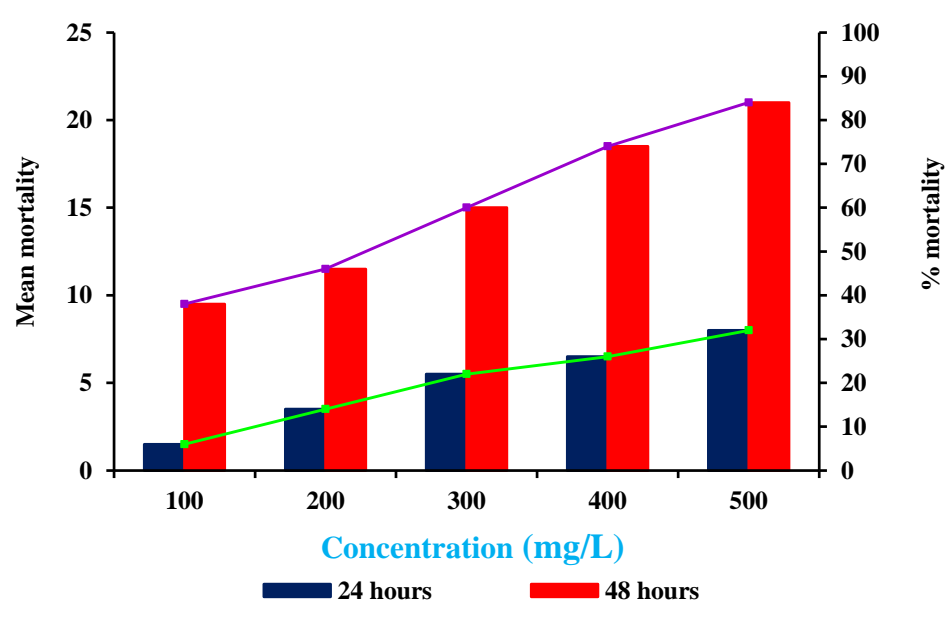

Figure 1 Mean and per cent larval mortality of Aedes aegypti by Citrus limon 


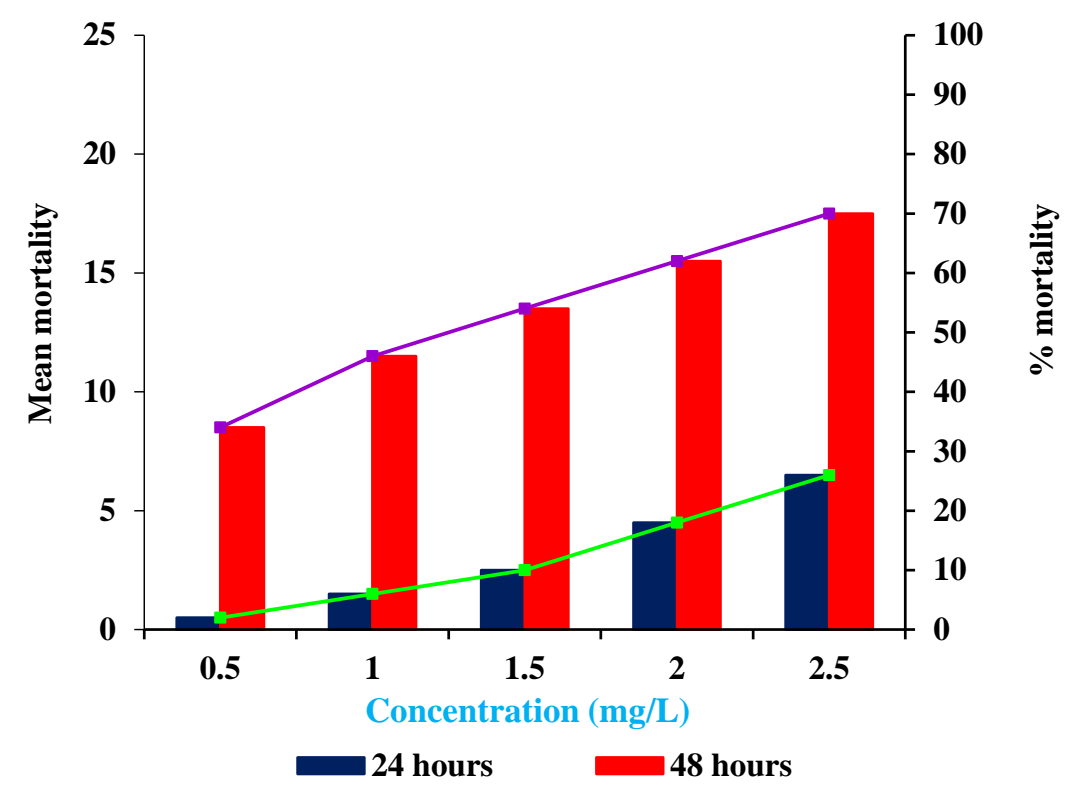

Figure 2 Mean and per cent larval mortality of Aedes aegypti by Bacillus thuringiensis

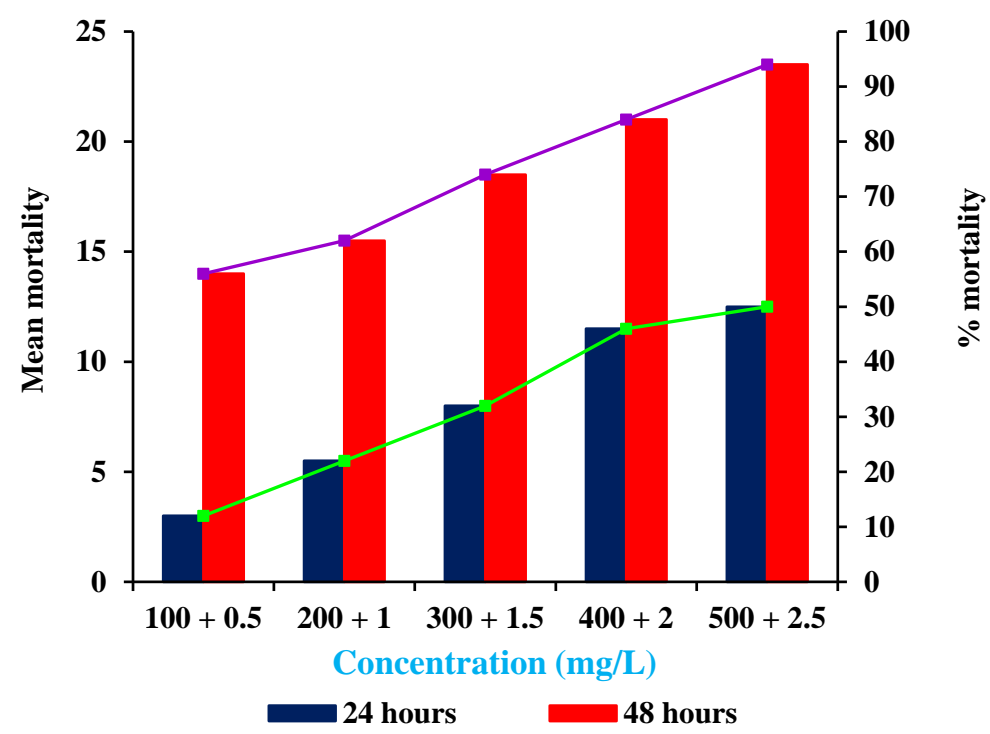

Figure 3 Mean and per cent larval mortality of Aedes aegypti by synergistic effect

Table 1 Statistical inferences on the mortality of Aedes aegypti larvae

\begin{tabular}{lllllll}
\hline Particulars & Hours & $\mathrm{LC}_{50}(\mathrm{mg} / \mathrm{L})$ & Regression & $\mathrm{R}^{2}$ & $\mathrm{~F}$ value & $\mathrm{P}$ value \\
\hline Citrus limon & 24 & 285.1 & $\mathrm{y}=0.16 \mathrm{x}+0.2$ & 0.9846 & 192.0 & 0.000814 \\
& 48 & 219.5 & $\mathrm{y}=0.13 \mathrm{x}+1.1$ & 0.9923 & 385.71 & 0.000288 \\
Bacillus & 24 & 1.9 & $\mathrm{y}=0.3 \mathrm{x}+6.1$ & 0.9923 & 96.43 & 0.002245 \\
thuringiensis & 48 & 1.4 & $\mathrm{y}=0.22 \mathrm{x}+6.7$ & 0.9918 & 363.0 & 0.000316 \\
$\begin{array}{l}\text { Citrus limon }+ \\
\text { Bacillus }\end{array}$ & 24 & 158.5 & $\mathrm{y}=0.25 \mathrm{x}+0.6$ & 0.9812 & 156.25 & 0.001104 \\
thuringiensis & 48 & 109.9 & $\mathrm{y}=0.25 \mathrm{x}+1.2$ & 0.9921 & 379.11 & 0.000296 \\
\hline
\end{tabular}




\section{Discussion}

The larval stages of mosquitoes are attractive targets for pesticides since they breed in water, which makes it easy to deal with them in this habitat. The use of conventional pesticides in the water sources, however, introduces many risks to the environment. Natural pesticides, especially those derived from plants, are more promising in this aspect. The genus Citrus has the potential to kill the larvae of Aedes aegypti and Aedes albopictus [14, 15, 33, 34]. Shrankhla and Kumar [35] indicated the Citrus limon peel waste extract to exhibit 75 to $100 \%$ mortality on the larvae of Culex quinquefasciatus. Akram et al. [15] reported Citrus limon essential oil to be effective against the fourth instar larvae of Aedes albopictus with a LC 50 of 137.258 ppm. Similarly, Din et al. [14] found its essential oil from fruit and peel extract to be toxic with $\mathrm{LC}_{50}$ of 468.69 and $395.59 \mathrm{ppm}$ respectively. Supenah et al. [36] tested the effect of Citrus limon juice against the third instar of Aedes aegypti at 5, 10, 15, 20 and $25 \%$ concentration and the average larval mortality after 48 hours of exposure was $100 \%$ from $10 \%$ concentration and $62 \%$ larval mortality for $5 \%$ concentration. Though this study exhibited 100\% larval mortality of Aedes aegypti, the concentrations were very high when compared to the present study. Phytochemicals produce impressive results and have proven efficiency in mosquito larval mortality. The variations in the composition of active ingredients (phenolics, saponins, flavonoids, alkaloids and tannins) observed among the extracts from the same species of Citrus fruit, reveals that the amount of active ingredients present in the different parts of the same species of Citrus fruits vary [37]. Citrus species are commonly known to contain flavonoids, coumarins and carotenoids and its bioactivities due to these bioactive compounds are affected by climate and geographical distribution [38]. Mallick et al. [39] found that alkaloids, terpenoids, steroids and flavonoids in Citrus maxima extract caused mortality to Culex quinquefasciatus larvae. The phytochemical contents in Citrus limon leaf extract include flavonoids and tannins which are reported to act as larvicides against Aedes aegypti. Flavonoids are poisonous phytocompounds and they enter the mouth of insect larva/ natural holes in the body of insects and cause immersion in the nerves. Further, they also cause protein clotting and protein denaturation which causes the permeability of the cell wall in the digestive tract to decrease which leads to disrupted nutrient transport leading to death of mosquito larvae. On the other hand, tannins, act as stomach poisons by reducing the activity of digestive enzymes and absorption of food [40]. Interestingly apart from the flavonoids and tannins, limonoids in Citrus species [41] exhibit a wide range of biological activities including insecticidal [42] and mosquitocidal [33, 43] especially larvicidal as they arrest the metabolic activities of the larvae [44]. Limonoids in Citrus limon are digestive larvicides and inhibit skin changes in larvae as they enter the body of mosquito larva and on entering the digestive organs, they disrupt the body's metabolism which results in a lack of energy for life activities which causes the larvae to spasm and eventually die [45]. All these features were observed in the larvae of Aedes aegypti treated to Citrus limon extracts in the present study.

Bacillus thuringiensis is pondered as the reference larvicidal agent for mosquito control operations at lethal doses as no resistance mechanism has been reported [12]. These toxins remain harmless to other insects, fish and animals and its essential toxin could act in a synergistic manner as no mechanism of resistance has been detected against mosquitoes [46]. Bacillus thuringiensis toxin possesses the capacity to breakdown the larval mid gut epithelium, after ingestion of the spore quickly dissolves in the lumen of the anterior stomach of larvae [47]. The toxins on reaching the midgut of the larvae disrupts the osmotic balance of the cells by forming pores in the cell membrane causing lysis of cell. The gut becomes paralyzed forcing the larvae to stop feeding and as a result, the larvae die within few hours of ingestion due to lethal septicaemia $[48,49]$. This may be due to the amount of toxin ingested, degree of larval midgut damage and the mode of action of the some of the components of binary toxins which synergically bind to specific receptors in larval midgut leading to formation of pores in the epithelial cell membrane which induce the death of larvae [50]. Further, Poopathi and Abidha [12] have reported in detail that these toxins in the insect digestive fluid travels across the peritrophic matrix and binds to specific receptors called cadherins on the brush border membrane of the gut cells resulting in activation of an oncotic cell death and concentrate on regions of the cell membrane called lipid rafts resulting in pore formation, osmotic cell shock, and ultimately larval death. However, it is to be noted that the binding of the toxin protein to the gastric caecum and posterior mid-gut has been observed in Culex pipiens as Aedes aegypti are resistant species [51].

The synergistic factor has been worked out and higher synergism was found in the present study on the larval instars. Synergism, combinational mode of action and counter-resistance effect are unique evolutionary traits of Bacillus thuringiensis which makes it the ideal biocontrol agent and explains why it is still the most efficient tool for mosquito control. As Bacillus thuringiensis produce a cocktail of toxins, and the mode of action is likely to involve the same mechanisms if not the same binding receptors, cross-resistance might evolve rapidly if botanical insecticides are used in combination with them. Ludlum et al. [52] have reported that aromatic compounds and plant allelochemicals increase the Bacillus thuringiensis activity. The addition of Bacillus thuringiensis with the plant extract have an adverse effect upon larval mortality and the same was observed in the present study too. The combined effect of Bacillus thuringiensis along with Citrus limon increased the mortality rate rather than the plant or microbe alone. During synergism, Bacillus 
thuringiensis and Citrus limon decreased the time to kill which increased the percentage of larval mortality when compared with treatment containing only Bacillus thuringiensis. The synergistic application of plant extracts with microbes produced a high mortality of the target organism due to increased toxicity. Their larvicidal activity is due to large amounts of proteins produced during sporulation and transformed into toxins under specific conditions after ingestion by mosquito larvae which is determined by both the structure of the proteins produced by the bacterium strain and the presence of proteolytic enzymes, and receptor in the midgut of mosquito larvae [53]. These factors would have played the key role in bringing about mortality in Aedes aegypti larvae in the present study. Moreover, the active phytocompounds in Citrus limon extract would have interacted with the toxins of Bacillus thuringiensis which could have certainly increased the toxicity against mosquito larvae.

\section{Conclusion}

In view of the above, the synergistic interaction of plant compounds from Citrus limon and toxins from Bacillus thuringiensis showed toxicity on the larvae of the dengue vector, Aedes aegypti. This study should thus promote the use of these natural biocides in the implementation of national policies for effective control of dengue vectors. Henceforth, the exploitation of plant chemicals and microbial pesticides can be suggested for use in mosquito vector control program for the control of mosquito-transmitted diseases. Moreover, adopting this kind of strategy would enable the use of pesticides that are safe for the environment in the future.

\section{Compliance with ethical standards}

\section{Acknowledgments}

The authors thank the Entomology Research Institute, Loyola College, Chennai, Tamil Nadu, India for providing the eggs of Aedes aegypti.

\section{Disclosure of conflict of interest}

The authors declare that there is no conflict of interest.

\section{References}

[1] WHO. (2014). A global brief on vector-borne diseases [Document number: WHO/DCO/WHD/2014.1]. Geneva, Switzerland.

[2] WHO. (2016). "Zika virus”, Fact sheet, World Health Organization.

[3] Liu H, Xu Q, Zhang L and Liu N. (2005). Chlorpyrifos resistance in mosquito Culex quinquefasciatus. Journal of Medical Entomology, 42(5), 815-820.

[4] Armadhani. (2014). Keefektifan Ekstrak Etanol Daun Petai Cina (Leucaena glauca, Benth) sebagai Larvasida Alami terhadap Kematian Larva Nyamuk Ae. aegypti instar III. Naskah Publikasi. Semarang: Universitas Negeri Semarang.

[5] Musau JK, Mbaria JM, Nguta JM, Mathiu M and Kiama SG. (2016). Phytochemical composition and larvicidal properties of plants used for mosquito control in Kwale County, Kenya. International Journal of Mosquito Research, 3(3), 12-17.

[6] Adnyani IGAP and Sudarmadja IM. (2016). Pengaruh Konsentrasi Ekstrak Etanol Daun Pepaya (Carica papaya L) terhadap Kematian Larva Nyamuk Aedes aegypti. E-Jurnal Medika, 5(8), 1-5.

[7] Palanikumar M, Pravin Y, Navaneethan M, Mahendren S, Mohanraj RS and Dhanakkodi B. (2017). Callistemon citrinus (Myrtaceae) methanolic leaf extract: a potent mosquitocidal agent for controlling dengue vector mosquito Aedes aegypti (Diptera: Culicidae). Journal of Entomology and Zoology Studies, 5(3), 1051-1059.

[8] Weisman Z and Chapagain B. (2003). Laboratory evaluation of natural saponin as a bioctive agent against Aedes aegypti and Culex pipiens. Dengue Bulletin, 27, 168-173.

[9] Weisman Z and Chapagain B. (2006). Larvicidal activity of saponin containing extracts and fractions of fruit mesocarp of Balanites aegyptiaca. Fitoterapia, 77, 420-424. 
[10] Rawani A, Ray AS, Ghosh A, Sakar M and Chandra G. (2017). Larvicidal activity of phytosteroid compounds from leaf extract of Solanum nigrum against Culex vishnui group and Anopheles subpictus. BMC Research Notes, $10,135-142$.

[11] Boudko DY, Moroz LL, Harvey WR and Linser PJ. (2001). Alkalinization by chloridebicarbonate pathway in larval mosquito midgut. Proceedings of the National Academy of Sciences of the United States of America, 26(98), 15355-15359.

[12] Poopathi S and Abidha S. (2010). Mosquitocidal bacterial toxins (Bacillus sphaericus and Bacillus thuringiensis serovar israelensis): Mode of action, cytopathological effects and mechanism of resistance. Journal of Physiology and Pathophysiology, 1(3), 22-38.

[13] Astarini NPF, Burhan RY and Zetra Y. (2009). Minyak atsiri dari kulit buah Citrus grandis, Citrus aurantium (L) dan Citrus aurantifolia (Rutaceae) sebagai senyawa antibakteri dan insektisida. Prosiding Kimia FMIPA-ITS, 8.

[14] Din S, Akram W, Khan HAA, Hussain A and Hafeez F. (2011). Citrus waste derived essential oils: Alternative larvicides for dengue fever mosquito, Aedes albopictus (Skuse) (Culicidae: Diptera). Pakistan Journal of Zoology, 43, 367-372.

[15] Akram W, Khan HAA, Hafeez F, Bilal H, Kim YK and Lee JJ. (2010). Potential of Citrus seed extracts against dengue fever mosquito, Aedes albopictus (Skuse) (Culicidae: Diptera). Pakistan Journal of Botany, 42, 3343-3348.

[16] Mallick S, Adhikari U, Rawani A and Chandra G. (2016). Phytochemical analyses and larvicidal potentiality of fruit peel extracts of Citrus limetta against filarial vector Culex quinquefasciatus. Journal of Mosquito Research, 6, 1-7.

[17] al Dakhil MA and Morsy TA. (1999). The larvicidal activity of the peel oils of three Citrus fruits against Culex pipiens. Journal of the Egyptian Society of Parasitology, 29(2), 347-352.

[18] Balaraman K, Balasubramanian M and Jambulingam P. (1983). Field trial of Bacillus thuringiensis H-14 (VCRC B17) against Culex and Anopheles larvae. Indian Journal of Medical Research, 77, 38-43.

[19] Medeiros FP, Santos MA, Regis L, Rios EM and Neto RPJ. (2005). Development of a Bacillus sphaericus tablet formulation and its evaluation as a larvicide in the biological control of Culex quinquefasciatus. Memórias do Instituto Oswaldo Cruz, 100, 431-434.

[20] Armengol G, Hernandez J, Velez JG and Orduz S. (2006). Longlasting effects of a Bacillus thuringiensis sero var israelensis experimental tablet formulation for Aedes aegypti (Diptera: Culicidae) control. Journal of Economic Entomology, 99, 1590-1595.

[21] Khyami HH, Katbeh BA and Mohsen ZH. (1999). Isolation of endospore forming bacilli toxic to Culiseta longiareolata (Diptera: Culicidae) in Jordan. Letters in Applied Microbiology, 128, 57-60.

[22] Darriet F and Hougard JM. (2002). An isolate of Bacillus circulans toxic to mosquito larvae. Journal of the American Mosquito Control Association, 18, 65-67.

[23] Das K and Mukherjee AK. (2006). Assessment of mosquito larvicidal potency of cyclic lipopeptides produced by Bacillus subtilis strains. Acta Tropica, 97, 168-173.

[24] Vogel. (1978). Textbook of practical organic chemistry, London, 1368.

[25] Harborne JB. (1998). Phytochemical methods, a guide to modern techniques of plant analysis, $3^{\text {rd }}$ Edition. Chapman and Hill Ltd., London, 279.

[26] Van Burden TP and Robinson WC. (1981). Formation of complexes between protein and tannin acid. Journal of Agricultural Food Chemistry, 1, 77.

[27] Obadoni BO and Ochuko PO. (2001). Studies and comparative efficacy of the crude extracts of some homostatic plants in Edo and Delta States of Nigeria. Global Journal of Pure and Applied Science, 8b, 203-208.

[28] Boham A and Kocipai AC. (1974). Flavonoids and condensed tannins from leaves of Hawaiia vaccinum vaticulatum and V. calyscinium. Pacific Science, 48, 458-463.

[29] Okwu DE and Okwu ME. (2004). Phytochemicals and vitamins content of indigenous plant species of south eastern Nigeria. Journal of Sustainable Agriculture and Environment, 6, 30-37.

[30] W.H.O. (2005). Guidelines for laboratory and field testing of mosquito larvicides. WHO, Geneva.

[31] Abbott WS. (1925). A method of computing the effectiveness of an insecticide. Journal of Economic Entomology, $18,265-267$. 
[32] SPSS. (2010). IBM SPSS Statistics for Windows, Version 22.0. Armonk, NY: IBM Corp.

[33] Hafeez F, Waseem A and Essam AS. (2011). Mosquito larvicidal activity of Citrus limonoids against Aedes albopictus. Parasitology Research, 109, 221-229.

[34] Warikoo R, Ray A, Sandhu JK, Samal R, Wahab N and Kumar S. (2012). Larvicidal and irritant activities of hexane leaf extracts of Citrus sinensis against dengue vector Aedes aegypti L. Asian Pacific Journal of Tropical Biomedicine, 2(2), 152-155.

[35] Shrankhla and Kumar S. (2018). Larvicidal activities of petroleum ether extracts of different fruit peel wastes against an Indian strain of filarial vector, Culex quinquefasciatus Say (Diptera: Culicidae). European Journal of Biomedical and Pharmaceutical Sciences, 5(2), 1074-1078.

[36] Supenah P, Taiman T and Sas OA. (2019). The effect of orange water of lemon (Citrus limon (L.) Osbeck) as a larvasid of Aedes Aegypti in third instar. Journal of Physics: Conference Series, 1360, 1-5.

[37] Effiom OE. (2019). Evaluation of the kill times of minimum concentrations of extracts from Citrus fruit peels, pulp and seeds tested against mosquito larvae and pupae. International Journal of Innovative Science and Research Technology, 4(6), 341-346.

[38] Kawaii S, Tomono Y, Katase E, Ogawa K, Yano M, Koizumi M, Chihiro I and Furukawa H. (2000). Quantitative study of flavonoids in leaves of Citrus plants. Journal of Agricultural and Food Chemistry, 48, 3865-3871.

[39] Mallick S, Mukherjee D, Ray AS and Chandra G. (2016). Larvicidal efficacy of fruit peel extracts of Citrus maxima against Culex quinquefasciatus. Journal of Mosquito Research, 6, 20.

[40] Wati FA. (2016). The effectiveness of sweet orange juice against Aedes aegypti third instar. University of Sebelas Maret, Surakarta.

[41] Fong CH, Hasegawa S, Herman Z and Ou P. (1990). Limonoid glucosides in commercial Citrus juices. Journal of Food Sciences, 54, 1505-1506.

[42] Champagne DE, Koul O, Isman MB, Scudder GGE and Towers GHN. (1992). Biological activity of limonoids from the Rutales. Phytochemistry, 31, 377-394.

[43] Jayaprakasha GK, Singh RP, Pereira J and Sakariah KK. (1997). Limonoids from Citrus reticulata and their moult inhibiting activity in mosquito Culex quinquefasciatus larvae. Phytochemistry, 44(5), 843-846.

[44] Senthilkumar N, Varma P and Gurusubramanian G. (2009). Larvicidal and adulticidal activities of some medicinal plants against the malarial vector, Anopheles stephensi (Liston). Parasitology Research, 104, 237-244.

[45] Prijadi DK and Wahongan GJP. (2016). The effectiveness of lime leaf extract in inhibiting the growth of larva of Aedes aegypti (Manado: Universitas Sam Ratulangi).

[46] Rozendaal JA. (1999). La lutte antivectorielle: Méthodes à usage individuel et communautaire. OMS, Genève, 946.

[47] Charles JF. (1987). Ultrastructural midgut events in Culicidae larvae fed with Bacillus sphaericus 2297 spordcrystal complex. Annales de l'Institut Pasteur. Microbiology, 138, 471-484.

[48] Adang MJ. (1991). Bacillus thuringiensis insecticidal crystal proteins: gene structure, action and utilization. In Biotechnology for biological control of pest and vectors. K. Maramorosh (Ed.) (CRC Press, Boca Raton, 1991), 324.

[49] Gill SS, Cowles EA and Pietranto PV. (1992). The mode of action of Bacillus thuringiensis endotoxins. Annual Review of Entomology, 37, 615-636.

[50] Schwartz JL, Potvin L, Coux F, Charles JF, Berry C, Humphreys MJ, Jones AF, Bernhart I, Serra DM and Menestrina G. (2001). Permeabilization of model lipid membranes by Bacillus sphaericus mosquitocidal binary toxin and its individual components. Journal of Membrane Biology, 184, 171-183.

[51] Baumann P, Clark MA, Bauman L and Broadwell AH. (1991). Bacillus sphaericus as a mosquito pathogen: Properties of the organism and its toxins. Microbiological Reviews, 55, 425-436.

[52] Ludlum CT, Felton GW and Duffey SS. (1991). Plant defenses: Chlorogenic acid and polyphenol oxidase enhance toxicity of Bacillus thuringiensis subsp. kurstaki to Heliothis zea. Journal of Chemical Ecology, 17, 217-237. 
[53] Kumar KP, Murugan K, Kovendan K, Kumar AN, Hwang JS and Barnard DR. (2012). Combined effect of seaweed (Sargassum wightii) and Bacillus thuringiensis var. israelensis on the coastal mosquito, Anopheles sundaicus in Tamil Nadu, India. Science Asia, 38, 141-146.

\section{How to cite this article}

Marin G, Arivoli S and Tennyson S. (2020). Synergistic larvicidal action of Citrus limon (L.) Osbeck (Rutaceae) and Bacillus thuringiensis Berliner 1915 (Bacillaceae) against the dengue vector Aedes aegypti Linnaeus 1762 (Diptera: Culicidae). GSC Biological and Pharmaceutical Sciences, 10(1), 25-33. 